\title{
Pelatihan PenggunaanMedia Aplikasi Penyuluhan Berbasis Android bagi PPL dan Ketua Kelompok Tani di Balai Penyuluh Pertanian (BPP) Kec. Hamparan Rawang Kota Sungai Penuh
}

\author{
Rendra, Jamaluddin, Fendria Sativa \\ Fakultas Pertanian, Universitas Jambi \\ Email corresponden author : yudra09@gmail.com
}

\begin{abstract}
Abstrak : Penyuluhan pertanian merupakan suatu proses komunikasi dan penyampaian informasi antara PPL (Penyuluh Pertanian Lapangan) dengan petani sebagai sasaran melalui kelompok tani. Dalam proses komunikasi terdapat proses belajar dengan menggunakan media agar pesan inovasi dan teknologi yang disampaikan dapat diserap dan diterima dengan baik oleh petani.Suatu media dapat dikatakan baik bilamana media tersebut dapat menyalurkan informasi dan komunikasi secara efektif dari pemerintah kepada petani. Media aplikasi penyuluhan berbasis android merupakan media yang kekinian menuju era revolusi industri 4.0 yang mampu mengakses informasi dan komunikasi secara efektif dan efisien dalam kegiatan penyuluhan pertanian.Dalam kaitan ini secara umum, tujuan program pengabdian ini adalah mengenalkan fungsi, manfaat dan cara menggunakan media aplikasi penyuluhan berbasis android kepada PPL dan Ketua Kelompok Tani. Dalam penggunaan media aplikasi penyuluhan yang berbasis android mempunyai keterkaitan kuat dalam peningkatan sumber daya manusia PPL dan Ketua Kelompok Tani dalam aspek ketrampilan dalam menggunakan media aplikasi penyuluhan berbasis android sesuai dengan kebutuhan sasaran sehingga dapat tercapainya tujuan dari penyuluhan pertanian yaitu diantaranya adalah menyampaikan pesan kebn ijakan pembangunan pertanian dan membantu petani memecahkan berbagai masalah yang dihadapinya. Kegiatan yang dilaksanakan dalam program ini mengacu kepada upaya peningkatan kemampuan dan ketrampilan PPL dan Ketua Kelompok Tani secara intensif dalam aspek penguasaan teknologi informasi dan multimedia, pengetahuan berbagai jenis aplikasi penyuluhan, dan upaya peningkatan ketrampilan PPL dan Ketua Kelompok Tani dalam mengakses aplikasi media penyuluhan yang ada secara baik dan mudah. Isi program tersebut adalah pemberdayaan PPL dan Ketua Kelompok Tani melalui pengembangan teknologi informasi dalam kegiatan penyuluhan pertanian dengan menggunakan aplikasi bidang pertanian yang berbasis android.Hasil dari pelaksanaan program Pengabdian ini antara lain pertama, dapat menambah pengetahuan dan ketrampilan PPL dan Ketua Kelompok Tani di BPP Kec. Hamparan Rawang Kota Sungai Penuh dalam hal penggunaan media aplikasi penyuluhan pertanian android.Kedua, menumbuhkan semangat dan motivasi yang kuat untuk mau menggunakan media aplikasi penyuluhan berbasis android dalam kegiatan penyuluhan pertanian.Ketiga, Meningkatkan kesadaran dan minat PPL dalam memanfaatkan fungsi dan peran aplikasi bidang pertanian secara efesien dan efektif baik dalam bertukar informasi dan komunikasi dalam penyuluhan pertanian serta dapat meningkatkan produksi dan pemasaran produk pertanian yang pada akhirnya dapat meningkatkan pendapatan dan kesejahteraan petani.
\end{abstract}

Kata Kunci : Teknologi Informasi Media Aplikasi dan Penyuluhan Pertanian.

\section{PENDAHULUAN}

Kehadiran Penyuluhan Pertanian Lapangan (PPL) dan peranan penyuluhan pertanian di tengah-tengah masyarakat tani di desa masih sangat dibutuhkan untuk meningkatkan sumber daya manusia (petani) sehingga mampu mengelola sumber daya alam yang ada secara intensif demi tercapainya peningkatan produktifitas dan pendapatan atau tercapainya ketahanan pangan dan ketahanan ekonomi. Penyuluhan adalah proses pembelajaran bagi pelaku utama serta perilaku usaha agar mereka mau dan mampu menolong dan mengorganisasikan dirinya dalam mengakses informasi pasar, teknologi, permodalan, dan sumber daya lainnya. Sebagai upaya untuk meningkatkan produktivitas, efisiensi usaha, pendapatan dan kesejahteraannya, serta meningkatkan kesadaran dalam pelestarian fungsi lingkungan (UU No.16 Tahun 2006, Sistem Penyuluhan Pertanian, Perikanan, dan Kehutanan).

Seiring perkembangan teknologi informasi dan komunikasi yang semakin pesat, maka program penyuluhan haruslah selalu memanfaatkan perkembangan teknologi tersebut untuk 
menuju petani milenial. Namun, sasarannya adalah para petani muda yang sudah aktif menggunakan android untuk kebutuhan komunikasi dan informasi dengan memanfaatkan jaringan internet. Adanya komunikasi tersebut ditandai dari berlangsungnya alih teknologi melalui proses uji coba yang dapat menghasilkan peningkatan produksi pada usaha tani yang dijalankan oleh petani. Di mana fungsi dari PPL adalah menjabarkan proses penyampaian ilmu dan teknologi dari sumberdaya kepada masyarakat tani yang membutuhkannya.

Sebagai sebuah kelembagaan penyuluhan, BPPKecamatan Hamparan Rawang melihat sangat penting adanya berbagai kegiatan yang berkaitan dengan usaha peningkatan kapasitas PPL dan Ketua Kelompok Tani.Karena itu untuk penyelenggaraan pelayanan kepada masyarakat, diperlukan secara terus-menerus memperbaiki kinerja PPL dalam memberikan pelayanan terhadap petani dan stakeholder. Termasuk meningkatkan kemampuan dan daya saing petugas penyuluh yang ada di wilayah BPP agar pelayanan terhadap petani tersebut terus mengalami perbaikan.

Berdasarkan uraian dan hasil diskusi dengan PPL serta berdasarkan pengamatan lapangan yang dilakukan pada saat survey pendahuluan maka masih ada beberapa masalah diantaranya yaitu;

a. Masih rendahnya kesadaran dan minat PPL dan Ketua Kelompok Tani terhadap pentingnya untuk menggunakan media aplikasi penyuluhan yang baik dalam kegiatan penyuluhan.

b. Masih minimnya pengetahuan dan ketrampilan PPL dalam menggunakan atau mengakses media aplikasi penyuluhan berbasis android.

c. Belum optimalnya dukungan pemerintah daerah dalam pemenuhan sarana dan prasarana serta pembiayaan dalam hal penyelenggaraan pendidikan tambahan berupa pelatihan bagi PPL terutama dalam hal meningkatkan ketrampilan bagi PPL dalam mengakses media aplikasi penyuluhan secara online.

\section{METODE KEGIATAN}

\subsection{MetodePendekatan} berikut:

Adapun tahapan pelaksanaan kegiatan pengabdian pada masyarakat adalah sebagai

1. Persiapan

Tahap awal pelaksanaan kegiatan pengabdian ini adalah membuat tutorial penggunaan media aplikasi penyuluhan. Setiap aplikasi memiliki informasi yang berbeda sesuai kebutuhan petani dan tutorial akan dibuat sebanyak 6 tutorial sesuai jenis media aplikasinya.

Membuat lembar pertanyaan sebagai alat evaluasi kegiatan pengabdian, dengan tujuan untuk memperoleh gambaran tentang sejauhmana pelatihan yang dilakukan dapat diserap, baik pada tingkat pemahaman maupun pada tahap ketrampilan untuk mempraktekkan. Mempersiapkan segala persiapan baik administrasi maupun peralatan serta fasilitas pelaksanaan pelatihan.

2. Sosialisasi

Kegiatan sosialisasi kepada kelompok sasaran yaitu PPL dan Ketua Kelompok Tani dilakukan terlebih dahulu mengenai teknis pelaksanaan kegiatan, jadwal kegiatan dan 
proses pelatihan penggunaanmedia aplikasi penyuluhan berbasis android. Di samping itu juga perlu di koordinasikan kepada pihak yang terkait dalam hal ini seperti Dinas Pertanian Tanaman Pangan dan Holtikultura Kota Sungai Penuh dan Lembaga Swadaya Masyarakat.

3. Pelaksanaan Kegiatan Pelatihan

Pada tahap pelaksanaan, kelompok sasaran yaitu para PPL dan Ketua Kelompok dikumpulkan di Kantor BPP. Kepala BPP memberikan arahan awal tentang maksud dan tujuan kedatangan Tim Pengabdian Fakultas Pertanian UNJA. Selanjutnya, kelompok sasaran diberikan ceramah tentang, (1) manfaat dan kegunaan media aplikasi penyuluhan; (2) memperkenalkan beberapa jenis media aplikasi penyuluhan yang dapat diakses oleh PPL dan Ketua Kelompok Tani; dan (3) cara-caramenggunakan media aplikasi penyuluhan yang baik dan benar untuk kegiatan penyuluhan.

Setelah pemberian ceramah, Tim Pengabdian mengajukan beberapa jenis media aplikasi penyuluhan yang dapat digunakan dalam kegiatan penyuluhan pertanian.

Pengenalan jenis media aplikasi penyuluhan berbasis android melalui diikuti dengan cara menggunakan dan memanfaatkannya. PPL dan Ketua Kelompok diberikan waktu bertanya atau menanggapi materi yang telah disampaikan,dengan harapan dapat memotivasi agar makin baiknya tingkat pemahaman mengenai materi pelatihan yang diberikan. Sebelumnya telah dibentuk beberapa kelompok kecil untuk melakukan diskusi sesama mereka dalam kelompok dan antarkelompok sesuai dengan ketersedian android dan fasilitas lainnya. Dalam hal ini, Tim Pengabdian berperan sebagai moderator dan nara sumber dalam penggunaan media aplikasi penyuluhan ini dan memberikan solusi atas masalah yang belum dapat diselesaikan oleh kelompok sasaran.

\section{Evaluasi Pelaksanaan Program dan Keberlanjutan Program}

Evaluasi dilakukan dengan asumsi bahwa tingkat pengetahuan seseorang terhadap sesuatu hal merupakan cerminan sikap untuk bertindak atau melakukan hal tersebut.

Untuk mengetahui sejauhmana keberhasilan kegiatan pengabdian yang telah dilakukan, maka Tim Pengabdian akan melakukan evaluasi terhadap tingkat pemahaman dan perubahan prilaku. Untuk mengetahui tingkat pemahaman dilakukan melalui lembar pertanyaan yang diberikan sebelum dan setelah pelaksanaan pengabdian. Sementara itu perubahan prilaku dilihat dari presentase para subyek yang telah dapat mempraktekkan cara menggunakan media aplikasi penyuluhan berbasis android sesuai dengan petunjuk tutorial yang telah disiapkan sebelumnya. Dalam hal ini evaluasi akan dilakukan pada sesi terakhir dari kegiatan pelatihan tersebut diberikan.

Untuk keberlanjutan program pengabdian ini dapat dilakukan kepada PPL dan Ketua Kelompok Tani yang ada di BPP pada Kecamatan yang lainnya dan yang paling penting untuk kelompok sasaran adalah dengan membuat pelatihan lanjutan tentang memanfaatkan secara aktif media aplikasi penyuluhan untuk kebutuhan petani dan menyelesaikan masalah yang dihadapi oleh petani.

\subsection{Materi Pengabdian}

\section{Petani}


Aplikasi ini memang diperuntukkan khususnya bagi para petani. Aplikasi ini dapat digunakan untuk membantu petani dalam meningkatkan produktivitas hasil tanaman. Melalui aplikasi ini, petani bisa bertanya langsung kepada pakarnya mengenai berbagai info mengenai dunia pertanian, cara budi daya tanaman yang baik, sampai cara mengatasi berbagai jenis penyakit yang bisa menyerang tanaman. Jadi, petani mendapatkan penyuluhan tentang berbagai hal terkait dunia pertanian secara online, kapan saja dan dari mana saja dengan memanfaatkan aplikasi ini.

\section{Pak Tani Digital}

Aplikasi ini memiliki berbagai fitur lengkap. Melalui aplikasi Pak Tani Digital ini petani bisa melakukan cek harga hingga pembelian barang langsung dari petani ke konsumen akhir. Fitur Transporter juga memudahkan petani untuk menemukan ekspedisi mana yang bisa digunakan untuk proses pengiriiman. Di samping itu dengan menggunakan media aplikasi ini petani juga bisa mengetahui mapping harga dan komoditi. Karena data harga yang dimiliki aplikasi ini bukan hanya data terbaru saja, tapi juga record data hingga 2 tahun terakhir.

\section{My Agri}

Aplikasi ini merupakan aplikasi di bidang Pertanian khususnya untuk tanaman sayuran yang memiliki fitur-fitur cukup lengkap, baik dalam aspek produksi, penyakit hama tanaman dan pasca panen serta pemasaran tentang info harga pasar. Melalui aplikasi ini petani bisa mengetahui jenis-jenis varietas tanaman sayuran, teknik budidaya tanaman sayuran, petani juga dapat menghitung kebutuhan pupuk untuk tanaman sayur, mengetahui jenis dan pengendalian hama penyakit, penggunaan pestisida, pengolahan, info harga sayuran, konsultasi dengan pakar sesuai dengan bidang yang dibutuhkan petani, info cuaca dan juga terdapat beberapa artikel ilmiah dalam bidang pertanian tanaman sayuran. Aplikasi ini memiliki 18 fitur yang tersedia yang siap membantu petani sayuran.

\section{Harga Pangan}

Aplikasi ini merupakan aplikasi di bidang Pertanian khususnya memberikan informasi harga dan perbandingan harga untuk beberapa komoditas seperti beras, daging ayam, daging sapi, telur ayam, bawang merah, bawang putih, cabai merah, cabai rawit, minyak goreng dan gula pasir. Informasi harga di sini memberikan informasi harga secara lengkap dengan 3 kategori harga yaitu harga pasar (jenis pasar), harga kota/kab (belum lengkap) dan harga provinsi (semua provinsi). Jenis pasar terdiri dari pasar tradisional, pasar modern, pedagang besar dan harga pada tingkat produsen. Aplikasi ini juga bisa menyajikan informasi degan membandingkan harga untuk komoditas dan pasar tertentu antara provinsi dan kabupaten dengan provinsi dan kabupaten lain yang ada dalam aplikasi. Informasi harga adalah harga yang diinfokan per hari, namun info telat bisa mencapai 3 hari.

\section{Katam Terpadu}

Aplikasi ini tersedia untuk komoditas padi, jagung dan kedelai. Aplikasi ini digunakan untuk memperkirakan kalender tanam, pupuk, alsintan dan varietas kerentanan di daerah kabupaten/kecamatan yang ada diseluruh indonesia. Aplikasi ini berada di bawah naungan Kementerian Pertanian. 


\section{Kalkulator Pertanian}

Aplikasi ini berisikan cara menghitung populasi, pupuk, jarak tanam, produksi dan konversi pupuk secara praktis dan mudah untuk tanaman padi, buah-buahan dan sayuran. Aplikasi ini bersifat off line tanpa menggunakan jaringan internet, sehingga lebih hemat. Aplikasi ini akan menambah pengetahuan dan kesadaran petani untuk tepat dan sesuai dalam menghitung kebutuhan populasi, pupuk, jarak tanam dan bisa menghitung produksi.

\section{HASIL DAN PEMBAHASAN}

\subsection{Sebelum Pelatihan}

Sebelum Pelatihan, dilakukan penyebaran angket atau daftar pertanyaan kepada semua peserta pelatihan untuk mengetahui pengetahuan dan ketrampilan dasar serta motivasi yang dimiliki oleh peserta pelatihan sebelum dilakukan pelatihan.

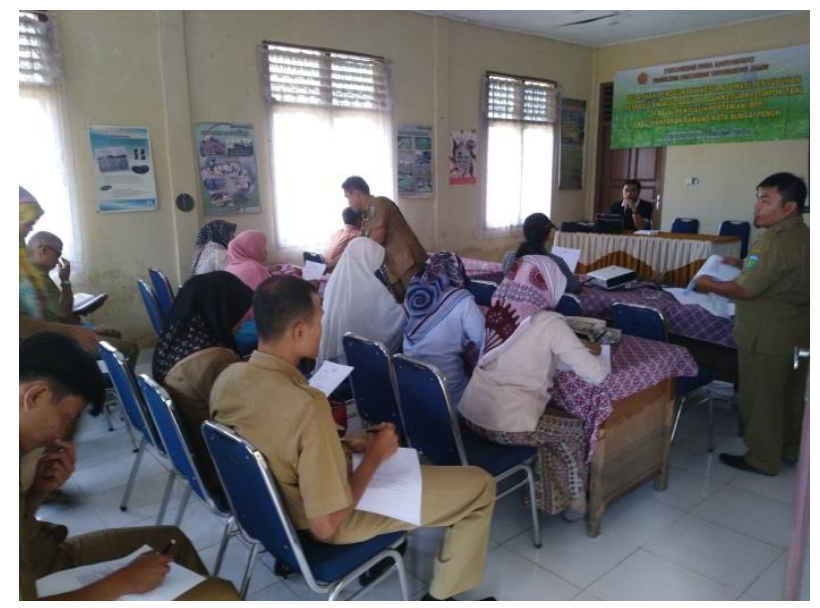

Dari hasil informasi diperoleh pengetahuan, ketrampilan dan motivasi peserta pelatihan bahwa mayoritas peserta yakni mencapai $89,48 \%$ belum memiliki pengetahuan umum tentang aplikasi bidang pertanian yang ada, begitu juga dengan ketrampilan bahwa walaupun terdapat peserta yang sudah mengetahui tentang aplikasi bidang pertanian yang ada, namun belum ada yang mampu secara terampil dalam menggunakan aplikasi tersebut. Sedangkan untuk motivasi dari peserta pelatihan untuk menggunakan aplikasi sebelum pelatihan dilakukan di ketahui sebagian besar juga memiliki motivasi yang tinggi untuk mengetahui dan mampu menggunakan aplikasi, terdapat $73,68 \%$ yang tertarik dengan aplikasi dan sisanya kurang tertarik. Hal ini dapat diketahui, walaupun peserta pelatihan belum mengetahui secara umum tetang aplikasi bidang pertanian tersebut, akan tetapi peserta pelatihan memiliki motivasi yang tinggi dikarenakan adanya rasa keingintahuan yang tinggi dari peserta terhadap aplikasi tersebut. Hal ini dapat disebabkan karena relatif tingginya tingkat pendidikan peserta yaitu antara SMA sampai Perguruan Tinggi. Di samping itu, lokasi Kecamatan Hamparan Rawang ini dekat sekali dengan pusat kota Sungai Penuh, yang hanya berjarak lebih kurang 3 KM saja dimana masyarakat Kecamatan Hamparan Rawang ini sangat tinggi mobilisasinya dalam berbagai aktivitas di Kota Sungai Penuh, bahkan sebagian kantor instansi pemerintah Kota Sungai Penuh berada di Kecamatan Hamparan Rawang.

\subsection{Proses Pelatihan}




\subsubsection{Penyampaian Materi}

Dalam proses pelatihan dilakukan 2 tahapan yaitu tahapan penyampaian materi dan tahapan praktek dan pendampingan. Dalam tahapan penyampaian materi dilakukan dengan cara ceramah dan diskusi atau tanya jawab bersama peserta, materi juga dipaparkan dengan menggunakan media infocus.

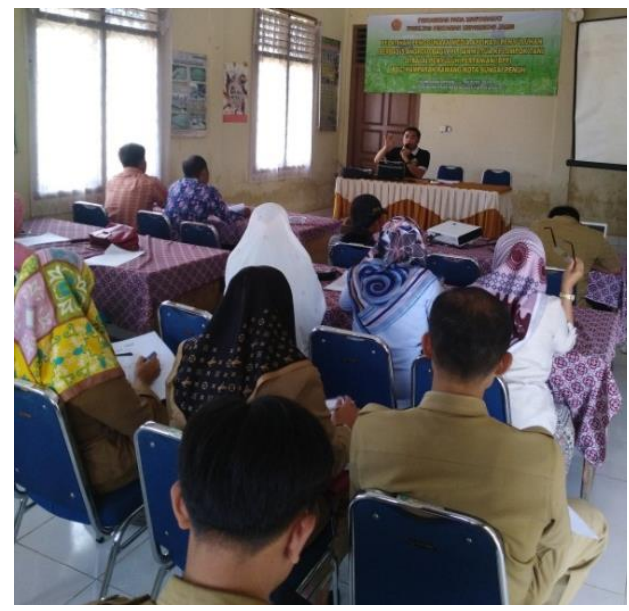

\subsubsection{Praktek dan Pendampingan}

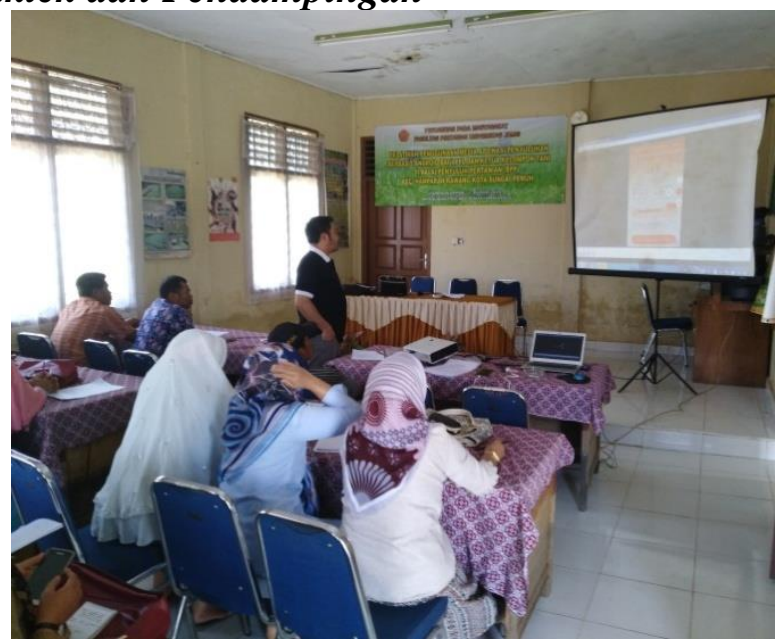

Dalam proses penyampaian materi dan praktek serta pendampingan, terlihat tingginya antusiasme dari peserta. Peserta yang terdiri PPL lebih cepat menyerap informasi yang disampaikan, hal ini bisa dilihat dari kemampuan praktek yang dilakukannya. Namun, peserta ketua kelompok tani yang mayoritas ibu-ibu memang memiliki berbagai kendala dalam mempraktekkan penggunaan aplikasi, sehingga peserta ketua kelompok lebih banyak bertanya terutama masalah praktek penggunaan aplikasi dengan baik. Namun, secara keseluruhan para peserta pelatihan diketahui cukup aktif dan mahir menggunakan android, namun lebih sering digunakan hanya untuk aktivitas media sosial, seperti facebook, instagram, whattshap, dan lain-lain.Dalam proses praktek dan pendampingan dilakukan juga dengan meminta bantuan PPL untuk mendampingi ketua kelompok taninya sehingga proses pendampingan menjadi lebih intensif dan peserta lebih cepat mampu menggunakan berbagai aplikasi bidang pertanian tersebut.

\subsection{Setelah Pelatihan (Evaluasi)}


Setelah pelatihan selesai maka dilakukan lagi evaluasi dengan cara mengisi angket atau daftar pertanyaan kepada seluruh peserta untuk mengetahui adanya perubahan dalam hal pengetahuan, ketrampilan dan motivasi peserta serta aplikasi apa saja yang paling diminati peserta pelatihan.

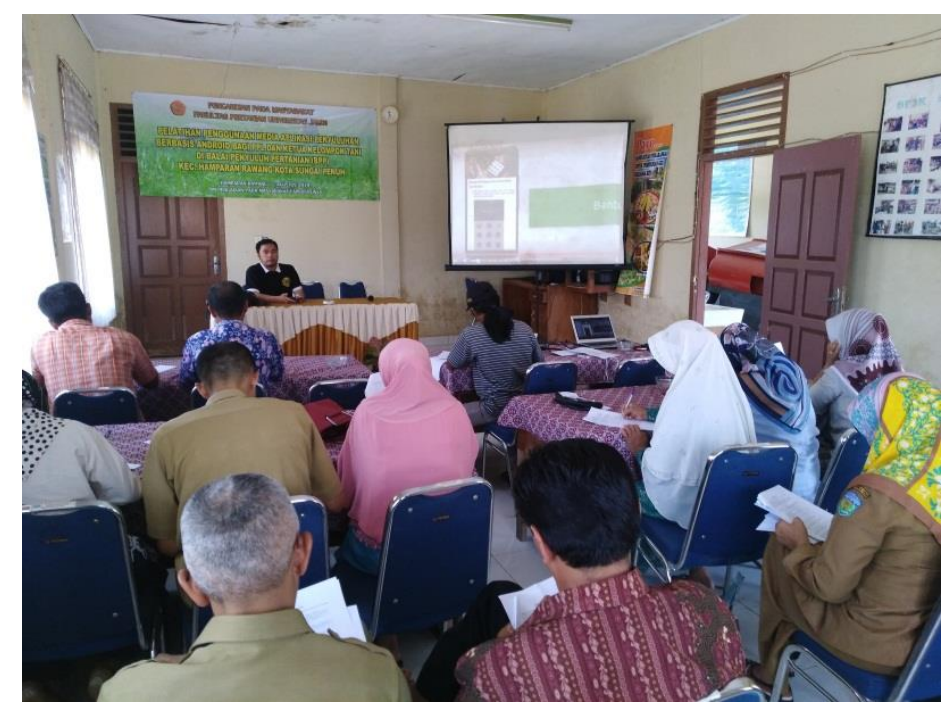

Dari hasil pelatihan dapat diketahui adanya perubahan-perubahan yaitu perubahan dalam aspek pengetahuan PPL dan ketua kelompok tani di Kecamatan Hamparan Rawang ini, dimana setelah mengikuti pelatihan ini diketahui $100 \%$ dari jumlah peserta dapat mengetahui fungsi dan manfaat dari penggunaan aplikasi bidang pertanian khususnya bidang pangan dan sayuran. Untuk aspek ketrampilan, terdapat $73,68 \%$ yang merasa sudah terampil dan masih tersisa 26,32\% saja yang masih kurang terampil dalam menggunakan aplikasi yang diberikan tersebut. Hal ini terjadi kepada peserta yang dari ketua kelompok tani yang mayoritas adalah ibu-ibu rumah tangga yang memiliki usia 50-60 tahun, yang nota bene belum terbiasa dan mahir dalam mengoperasikan android. Sedangkan untuk motivasi diketahui bahwa PPL dan ketua kelompok tani semuanya $100 \%$ memiliki motivasi yang tinggi untuk mau dan dapat menggunakan aplikasi bidang pertanian ini sesuai dengan kebutuhannya. Untuk aplikasi yang diminati oleh peserta antara lain Pak Tani Digital 100\%, My Agri 47,37\%, Katam 21,05\%, Petani 47,37\%, Harga Pangan 47,37\% dan Kalkulator Pertanian 100\%. Tinginya minat pada Pak Tani Digital dikarenakan dianggap memiliki fitur yang lengkap dan menarik serta sesuai dengan kebutuhan petani. Begitu juga dengan aplikasi Kalkulator Pertanian dianggap aplikasi paling simpel atau sederhana dan mudah untuk digunakan dan diterapkan. Sedangkan aplikasi lainnya seperti My Agri, Petani, dan Harga Pangan ternyata hanya sebagian peserta pelatihan saja yang tertarik, hal ini dikarenakan terlalu rumit, kurang lengkap dan tingkat kesesuaian dengan kebutuhan petani yang kurang. Di samping itu aplikasi katam (kalender tanam) paling rendah diminati, hal ini dikarenakan aplikasinya dianggap peserta pelatihan kurang bermanfaat dan kurang bisa untuk diterapkan.

\section{KESIMPULAN}

Kegiatan pengabdian yang dilakukan melalui pelatihan mampu meningkatkan pengetahuan PPL dan ketua kelompok tani tentang jenis, kegunaan dan manfaat dari berbagai 
aplikasi bidang pertanian berbasis android tersebut. Di samping itu kegiatan ini juga dapat memberikan motivasi dan meningkatkan kemampuan serta ketrampilan bagi PPL dan ketua kelompok tani dalam menggunakan berbagai aplikasi bidang pertanian tersebut berbasis android. Sehingga, setelah kegiatan pelatihan ini bahwa PPL dan ketua kelompok tani memiliki banyak harapan terkait aplikasi yang ada yaitu dengan memberikan informasi terbaru terhadap perkembangan bidang pertanian, lebih spesifik, pengetahuan sesuai dengan kebutuhan, lebih lengkap lagi, lebih update dan lebih simpel. Selain itu, sampel mengharapakan ada aplikasi bidang pertanian lebih lokalistik tingkat provinsi Jambi dan Kota Sungai Penuh sehingga aplikasi tersebut sangat bermanfaat dan bisa diterapkan dengan optimal oleh petani.

\section{Acknowledgment}

Ucapan terima kasih penulis sampaikan kepada Universitas Jambi yang telah mendanai kegiatan pengabdian PPM ini melalui sumber Dana DIPA-PNBP LPPM Penerapan IPTEK Nomor SP-DIPA-042.01.2.400950/2019 tangal 5 Desember 2018, dan Surat Perjanjian Penugasan dalam Rangka Pelaksanaan Pengabdian Kepada Masyarakat Nomor : B/65/UN21.18/PM.01.01/2019 tanggal 7 Mei 2019

\section{DAFTAR PUSTAKA}

Anonim, 2010. Data Penyuluh BP3K Kec. Pemayung Kab. Batanghari, 2010.Jambi.

Kartasapoetra A. G. 1998. Teknologi Penyuluhan Pertanian. BumiAksara. Jakarta.

MardikantoTotok. 1993. Penyuluhan Pembangunan Pertanian. UsahaNasional. Surabaya.

Sugarda, Sudarmanto, Sumintaredja, 2001. PenyuluhanPertanian. Yayasan Pengembangan Sinar Tani. 2001.

Soekartawi.2005. PrinsipDasarKomunikasiPertanian. UniversitasIndonesia. Jakarta. 